\title{
Removal of Remazol Black B dye using bacterial cellulose as an adsorbent
}

Remoção do corante Remazol Black B usando celulose bacteriana como adsorvente

\author{
A. N. R. Leal ${ }^{1 *}$; A. C. A. Lima ${ }^{1}$; M. G. F. A. Azevedo²; D. K. D. N. Santos ${ }^{2}$; L. E. \\ M. C. Zaidan ${ }^{3}$; V. F. Lima ${ }^{3}$; I. J. Cruz Filho ${ }^{2, *}$ \\ ${ }^{1}$ Graduate program in materials sciences, Federal University of Pernambuco, 50740-560, Recife - PE, Brazil. \\ ${ }^{2}$ Department of Antibiotics, Federal University of Pernambuco,50670-420, Recife - PE, Brazil. \\ ${ }^{3}$ Department of Chemical Engineering, Federal University of Pernambuco,50740-590, Recife - PE, Brazil. \\ *iranildoj@gmail.com \\ (Recebido em 21 de novembro de 2020; aceito em 22 de março de 2021)
}

\begin{abstract}
Effluents from textile processes, when discarded of inappropriately, have been shown to be a major environmental concern. In this way, different methods can be used, among them adsorption is an economical and efficient technique in the removal of dyes. Therefore, we propose to analyze the adsorptive capacity of bacterial cellulose (CB) against effluents containing the dye Remazol Black B (RBB). CB was produced by the bacterium Gluconacetobacter hansenii and characterized by the techniques of FTIR, DRX, TGA / DTG and $\mathrm{pH}$ (PCZ). The RBB removal tests were initially performed at different pHs. From the best experimental condition, new tests were performed at temperatures of $30,40,60$ and $100 \pm 2{ }^{\circ} \mathrm{C}, 150 \mathrm{rpm}, \mathrm{pH} 3.5$, using $0.5 \mathrm{~g}$ of adsorbent in the concentrations of dye from 25 to $65 \mathrm{mg} \cdot \mathrm{L}^{-1}$. The kinetic study showed that the system balance was achieved in 80 minutes. The experimental data were better described by the pseudosecond order model. The equilibrium results showed that the experimental data fit the Langmuir model $\left(\mathrm{q}_{\max }\right.$ $\left.17.513 \mathrm{mg} \cdot \mathrm{g}^{-1}\right)$. The thermodynamic parameters of adsorption showed that the process is exothermic, not spontaneous and also presented low system randomness. The activation energy (Ea) was $23.8 \mathrm{~kJ}^{\mathrm{mol}}{ }^{-1}$ characterizing physical adsorption. The residual water was not toxic to animal or microbial cells. Bacterial cellulose proved to be a good low-cost adsorbent, easy to acquire and which can be used in the adsorption process.
\end{abstract}

Keywords: bacterial cellulose, biosorption, Remazol Black B.

Efluentes de processos têxteis, quando descartados de forma inadequada, têm se mostrado uma grande preocupação ambiental. Desta forma, diferentes métodos podem ser utilizados, dentre eles a adsorção é uma técnica econômica e eficiente na remoção de corantes. Portanto, nós propomos a analisar a capacidade adsortiva da celulose bacteriana (CB) frente a efluentes contendo o corante Remazol Black B (RBB). A CB foi produzida pela bactéria Gluconacetobacter hansenii e caracterizada pelas técnicas de FTIR, DRX, TGA / DTG e pH (PCZ). Os testes de remoção do RBB foram realizados inicialmente em diferentes pHs. A partir da melhor condição experimental, novos testes foram realizados nas temperaturas de $30,40,60$ e $100 \pm 2{ }^{\circ} \mathrm{C}$, $150 \mathrm{rpm}, \mathrm{pH} 3,5$, utilizando $0,5 \mathrm{~g}$ de adsorvente nas concentrações de corante de $25 \mathrm{a} 65 \mathrm{mg} \cdot \mathrm{L}^{-1}$. O estudo cinético mostrou que o equilíbrio do sistema foi alcançado em 80 minutos. Os dados experimentais foram melhor descritos pelo modelo de pseudo-segunda ordem. Os resultados de equilíbrio mostraram que os dados experimentais se ajustam ao modelo de Langmuir $\left(\mathrm{q}_{\max } 17,513 \mathrm{mg} \cdot \mathrm{g}^{-1}\right)$. Os parâmetros termodinâmicos de adsorção mostraram que o processo é exotérmico, não espontâneo e também apresentou baixa aleatoriedade do sistema. A energia de ativação (Ea) foi de $23,8 \mathrm{~kJ} \cdot \mathrm{mol}^{-1}$ caracterizando adsorção física. A água residual não foi tóxica para as células animais ou microbianas. A celulose bacteriana mostrou-se um bom adsorvente de baixo custo, fácil de adquirir e que pode ser utilizado no processo de adsorção.

Palavras-chave: celulose bacteriana, biossorção, Remazol Black B.

\section{INTRODUCTION}

The global textile industry is the fastest growing sector economically. World trade in textile fibers - natural and chemical (synthetic / artificial). The sector had revenues of around US \$ 1.9 trillion in 2019 and in 2030 this revenue is expected to be US \$ 3.3 trillion .Brazil is the 5th largest world producer of textiles, its industries generate approximately 1.5 million direct employees [1]. This industrial segment is one of the largest consumers of water $[1,2]$. And it is estimated that 
during the dyeing and finishing stages, around 50 to $100 \mathrm{~L}$ of effluent are produced per kilogram of fabric produced $[3,4]$.

Among these compounds present in the textile effluent there are dyes, complex molecules whose purpose is to give coloring to synthetic or natural fibers $[5,6]$. When discarded inappropriately in aquatic environments, it prevents the penetration of sunlight into the deeper layers, altering the photosynthetic activity of the environment, decreasing the oxygen solubility, and resulting in toxic effects on aquatic fauna and flora [7]. In addition, azo-type dyes (Remazol Black B, for example) can decompose into aromatic amines with possible carcinogenic potential under anaerobic conditions[7, 8].

Due to this problem, different treatments have been used for the remediation of environments contaminated by dyes, among them oxidation or ozonation, electrochemical treatment, reverse osmosis, precipitation, coagulation and flocculation, membrane separation and photochemical degradation can be mentioned $[9,10]$. However, these methods are not widely used due to their high cost [10]. An alternative method for the treatment of textile effluents is adsorption, an efficient and economical process that involves the adhesion of molecules of the fluid (pollutant) on the solid surface of the adsorbent (biological matrix) [11, 12]. Different adsorbents of synthetic or natural origin can be used to remove contaminants [13]. Among these, bacterial cellulose (CB), obtained by different bacteria has shown to be very promising, as it has functional groups on its surface capable of capturing these contaminants [14]. In addition to being a renewable and easily obtainable material $[15,16]$.

Studies have shown how effective the adsorbents from bacterial cellulose are in the treatment of textile effluents. CB was able to adsorb $654 \mathrm{mg} \cdot \mathrm{g}^{-1}$ of the Congo red dye in solution [17]. Chen et al. (2020) [18], also studying the adsorption of the Congo red dye obtained an adsorptive capacity of $230 \mathrm{mg} \cdot \mathrm{g}^{-1}$. Ali et al. (2012) [19] obtained $25 \mathrm{mg} \mathrm{g}^{-1}$ against the direct blue dye 15 . The activated carbon obtained from bacterial cellulose was able to adsorb $507.5 \mathrm{mg} \cdot \mathrm{g}^{-1}$ from the methylene blue dye [20]. When functionalized, CB also shows good removal results. Studies by Huang et al. (2020) [21] with PEI-Pt modified CB showed that this material was able to capture $1157.9 \mathrm{mg} \cdot \mathrm{g}^{-1}$ of the acid-black dye and $13.5 \mathrm{mg} \mathrm{g}^{-1}$ of methylene blue. These results reveal how potential bacterial celluloses are for the treatment of textile effluents.

This work aimed to obtain and characterize the bacterial cellulose produced by Gluconacetobacter hansenii and use it as an adsorbent for the removal of the Remazol Black B dye in synthetic solutions. The influence of $\mathrm{pH}$ on the solution and temperature were investigated. In addition to kinetic, equilibrium and thermodynamic studies of the adsorption process.

\section{MATERIAL AND METHODS}

\subsection{Production of adsorbent: bacterial cellulose}

\subsubsection{Microorganism and culture medium}

The microorganism used in this study was the bacterium Gluconacetobacter hansenii, from the collection of microorganisms from the Industrial Microbiology Laboratory located in the Department of Chemical Engineering at the Federal University of Pernambuco. The culture medium used for microbial maintenance was Hestrin-Schramm (HS) composed of: $\left(20 \mathrm{~g} \cdot \mathrm{L}^{-1}\right)$ glucose (Merck Millipore, CAS 77938-63-7); $\left(5 \mathrm{~g} \cdot \mathrm{L}^{-1}\right)$ meat peptone (Merck Millipore, CAS 91079-38-8); (5 g. $\mathrm{L}^{-1}$ ) yeast extract (Merck Millipore, CAS 8013-01-2); (2.7 g. $\left.\mathrm{L}^{-1}\right) \mathrm{Na}_{2} \mathrm{HPO}_{4}$ (Merck Millipore, CAS 7558-79-4); (1.15 g. $\mathrm{L}^{-1}$ ) citric acid (Merck Millipore, CAS 77-92-9) and $\left(15 \mathrm{~g} \cdot \mathrm{L}^{-1}\right)$ bacteriological agar (Merck Millipore, CAS 9002-18-0).

\subsubsection{Inoculum production}

The inoculum was produced according to the methodology proposed by Coimbra (2016) [22]. The culture of $G$. hansenii was initially activated in HS broth (without the addition of 
bacteriological agar). After broth incubation for $48 \mathrm{~h}$ at $30^{\circ} \mathrm{C}, 100 \mu \mathrm{L}$ of this culture was sown in $90 \mathrm{~mm}$ diameter Petri dishes containing solid HS (obtained by adding bacteriological agar), the volume being distributed over the entire surface of the medium with the aid of a Drigalski handle. The plates were incubated for seven days at $30{ }^{\circ} \mathrm{C}$ for growth of cell mass on the surface of the medium. The grown cell mass was transferred to Erlenmeyer flasks containing HS broth in a volume equivalent to $1 / 5$ of its capacity and maintaining the biomass proportion, that is, two plates for each $50 \mathrm{~mL}$ of broth. The medium was subjected to stirring with a magnetic bar until the lumps of cells and cellulose were broken up and incubated at $30 \pm 1^{\circ} \mathrm{C}$ and $150 \mathrm{rpm}$ of agitation for $48 \mathrm{~h}$, before being used as inoculum.

\subsubsection{Adsorbent production}

For the production of the adsorbent, the modified HS culture medium composed of: $\left(5 \mathrm{~g} \cdot \mathrm{L}^{-1}\right)$ meat peptone (Merck Millipore, CAS 91079-38-8); (5 g. $\left.\mathrm{L}^{-1}\right) \mathrm{Na}_{2} \mathrm{HPO}_{4}$ (Merck Millipore, CAS 7558-79-4); (1.15 $\left.\mathrm{g} \mathrm{L}^{-1}\right)$ citric acid (Merck Millipore, CAS 77-92-9) and molasses (20 g. $\left.\mathrm{L}^{-1}\right)$. In the middle, $1 \%$ of the $G$. hansenii bacterium was inoculated. The experiments were carried out in $3 \mathrm{~L}$ Fernbach flasks containing the modified HS culture medium (1L) at $30^{\circ} \mathrm{C}, \mathrm{pH} 6.0$ in static condition for 7 days. After cultivation, the cellulose (Figure 1) was removed from the culture medium and washed with a $1.0 \mathrm{~mol} \cdot \mathrm{L}^{-1} \mathrm{NaOH}$ solution (Merck Millipore, CAS 1310-73-2) at 90 ${ }^{\circ} \mathrm{C}$ for $1 \mathrm{~h}$, then were washed in distilled water. All experimental procedures were performed aseptically.

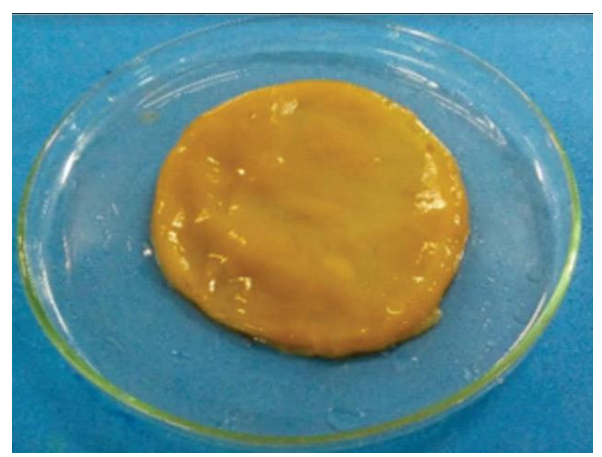

Figure 1. Bacterial cellulose produced by Gluconacetobacter hansenii in HS culture medium based on molasses.

\subsection{Physical and chemical characterization of the adsorbent}

\subsubsection{Determination of moisture and ash content}

The moisture content was determined by drying the samples in an oven (Tecnal, TE-393/1) at $105 \pm 2{ }^{\circ} \mathrm{C}$ for 8 hours. This analysis helped to determine the wet and dry mass. After drying, the cellulose was crushed and sieved in a range of $100 \mu \mathrm{m}$. The total ash content was determined by measuring the residue obtained after the material was incinerated in a muffle furnace (Thermo scientific) at $650 \pm 5^{\circ} \mathrm{C}$ for 4 hours. All analyzes were performed in triplicate.

\subsubsection{Infrared spectroscopy with fourier transform (ATR-FTIR)}

ATR-FTIR analysis was used to identify the main functional groups of the adsorbent. For this, a Bruker Tensor 27 spectrometer with the attenuated total reflectance accessory (Platinum ATR) was used. The spectra were recorded in the spectral range from 4000 to $500 \mathrm{~cm}^{-1}$, with a resolution of $2 \mathrm{~cm}^{-1}$ and 20 scans. 


\subsubsection{X-ray diffraction- $(D R X)$}

In order to evaluate the behavior of the cellulose structure, that is, crystalline and amorphous regions, an X-ray diffractometer (XRD-6000 / Shimadzu) was used. The applied conditions were: $40 \mathrm{kV}$, angular range $4^{\circ}$ to $60^{\circ}$ (Bragg - $2 \theta$ angle), angular variation $0.05^{\circ}$ and counting time of $1 \mathrm{~s}$. Through Equations 1 and 2 it was possible to determine the values of the average width of the crystallites in the lattice plane of greater intensity $(D h k l)$ and the crystallinity index $(\mathrm{CI})$.

$$
\begin{gathered}
D h k l=K \lambda \beta \cos \theta \\
I C(\%)=\left[\left(\frac{I_{002}-I_{a m}}{I_{002}}\right)\right] * 100 \%
\end{gathered}
$$

Where: $\mathrm{D}$ - average particle diameter, $\mathrm{K}$-constant depending on the shape of the particles (sphere $=0,94), \lambda$ - wavelength of electromagnetic radiation, $\theta$ - diffraction angle, $\beta(2 \theta)$ - width in half diffraction peak height. \% CI: Crystallinity index, I002: Intensity in the crystalline peak at approximately $2 \theta, \mathrm{I}_{\mathrm{am}}$ : Intensity relative to the amorphous region.

\subsubsection{Determination of the zero-charge point ( $\mathrm{pH} \mathrm{Hpz}$ )}

The zero-charge point $(\mathrm{PCZ})$ is the $\mathrm{pH}$ value at which the adsorption of potential-determining ions $\left(\mathrm{H}^{+}\right.$and $\left.\mathrm{OH}^{-}\right)$are equal. To determine the PCZ, the methodology proposed by Silva et al. (2018) [23] and Hassan et al. (2019) [24] with modifications. The tests consisted of the addition of $20 \mathrm{mg}$ of the adsorbent $(100 \mu \mathrm{m})$ in $20 \mathrm{~mL}$ of aqueous solution of $\mathrm{NaCl} 0.1 \mathrm{~mol} \cdot \mathrm{L}^{-1}$, under different conditions of initial $\mathrm{pH}(3.5 ; 4 ; 5 ; 6 ; 7 ; 8 ; 9 ; 10 ; 11)$, adjusted with $3 \mathrm{M} \mathrm{HCl}$ or $\mathrm{NaOH}$ solutions. After $24 \mathrm{~h}$ of equilibration on a shaking table (New Brunswick Scientific, model C25KC) at 100 $\mathrm{rpm}$ and $30{ }^{\circ} \mathrm{C}$, the solutions are filtered and the final $\mathrm{pH}$ determined solution. All tests were performed in triplicate.

\subsection{Synthetic effluent}

The synthetic dye used in the adsorption tests was Remazol Black B (RBB) (Sigma-Aldrich, CAS 17095-24-8) (Figure 2).

The solutions were prepared with distilled water. The concentrations of the solutions were diluted from a stock solution $\left(100 \mathrm{mg} \cdot \mathrm{L}^{-1}\right)$. To adjust the $\mathrm{pH}$ of the solutions, solutions of hydrochloric acid (Merck Millipore) and sodium hydroxide (Merck Millipore, CAS 1310-73-2), both $3 \mathrm{~mol} \cdot \mathrm{L}^{-1}$, were used. The initial and final concentrations of the initial dye solution were determined by a spectrophotometer (Hewlett-Packard, model 8453), measuring the absorbance at a length of $597 \mathrm{~nm}$, with water as white.

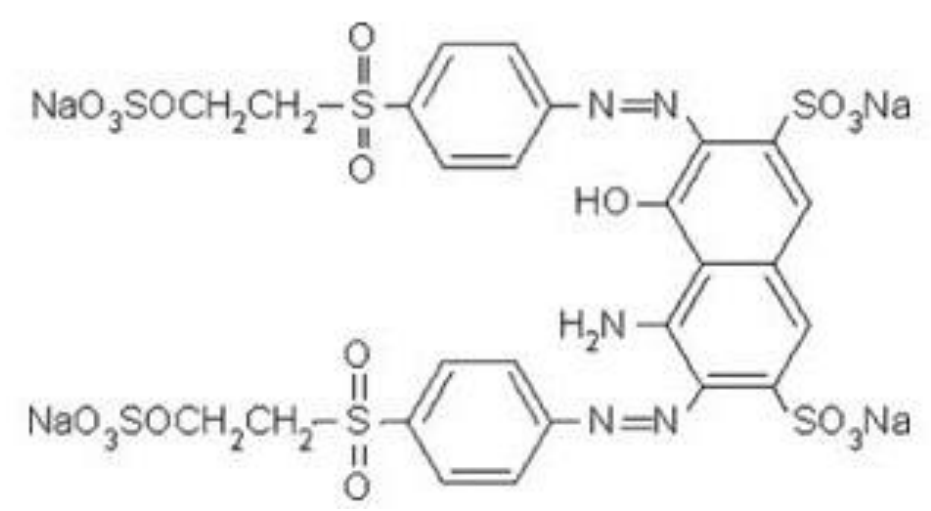

Figure 2. Chemical structure of Remazol Black B dye 


\subsection{Adsorption tests}

\subsubsection{Influence of $\mathrm{pH}$ on the adsorption process}

The influence of $\mathrm{pH}$ was assessed according to studies by Cruz et al. (2016) [25] and Nascimento et al. (2017) [26] with few modifications. The adsorbent was subjected to tests conducted in a batch system, varying only the initial $\mathrm{pH}$ value of the solution (3.5 to 9). The fixed experimental conditions were: mass of the adsorbent $(0.5 \mathrm{~g})$ and the concentration of the dye solution $\left(25 \mathrm{mg} \cdot \mathrm{L}^{-}\right.$ ${ }^{1}$ ). The system was conducted at $30^{\circ} \mathrm{C}, 150 \mathrm{rpm}$ and a contact time of 12 hours. At the end of each test, the samples were centrifuged at $3000 \mathrm{rpm}$ for 10 minutes and then the final concentrations of the solutions were read on a UV-Vis spectrophotometer at $597 \mathrm{~nm}$ with water as white. Through the results it was possible to determine the highest percentage of removal, this value was determined using Equation 3.

$$
R(\%)=\frac{\left(C_{o}-C_{e}\right)}{C_{o}} * 100 \%
$$

Where: $\mathrm{C}_{\mathrm{o}}$ is the concentration of the solute in the initial solution $\left(\mathrm{mg} \mathrm{L}^{-1}\right) ; \mathrm{C}_{\mathrm{e}}$, refers to the residual concentration in the equilibrium $\left(\mathrm{mg} \mathrm{L}^{-1}\right)$.

\subsubsection{Adsorption kinetics}

The study of adsorption kinetics was carried out with the objective of establishing the ideal contact time between the adsorbent and the adsorbate [27]. For this, the experiments were carried out in a batch system under conditions previously determined by Cruz et al. (2016) [25] and Nascimento et al. (2017) [26], with few modifications. The adsorbent $(0.5 \mathrm{~g})$ was subjected to an aqueous solution $25 \mathrm{mg} \mathrm{L}^{-1}$ of RBB dye $(100 \mathrm{~mL})$. The system was kept under agitation at $150 \mathrm{rpm}$ on a shaking table (New Brunswick Scientific, model C25KC), with pH 3.5 and the aliquots were analyzed, in the time interval between 0 and 120 minutes.

The study was conducted at three different temperatures $\left(30,40,60\right.$ and $\left.100 \pm 2{ }^{\circ} \mathrm{C}\right)$ and $5.0 \mathrm{~mL}$ samples were taken at 2-minute intervals to be analyzed, and subsequently centrifuged at $5000 \mathrm{rpm}$ for 3 minutes. The supernatant was analyzed by spectrophotometry to determine the final concentration. The determination of adsorptive capacity was determined by Equation 4 .

$$
q=m \frac{\left(C_{o}-C_{e}\right)}{M}
$$

Where: $\mathrm{q}$ is the adsorption capacity $\left(\mathrm{mg} \cdot \mathrm{g}^{-1}\right), \mathrm{C}_{\mathrm{o}}$ is the concentration of the solute in the initial solution $\left(\mathrm{mg} \cdot \mathrm{L}^{-1}\right) ; \mathrm{C}_{\mathrm{e}}$, refers to the residual concentration in the equilibrium $\left(\mathrm{mg} \cdot \mathrm{L}^{-1}\right) ; \mathrm{V}$ corresponds to the volume of the solution $(\mathrm{L}) ; \mathrm{m}$ is the amount of mass of the adsorbent $(\mathrm{g})$.

In order to know some characteristics about the adsorption kinetics of RBB in cellulose, the experimental data obtained in the kinetic study were evaluated by three kinetic models, namely: the pseudo-first order, pseudo-second order and intraparticle diffusion models (Morris-Weber) using Linear Equations 5, 6 and 7 [25, 28, 29].

$$
\begin{aligned}
& \log \left(q_{e}-q_{t}\right)=\log \left(q_{e}\right)-\frac{k_{1}}{2,303} t \\
& \frac{t}{q_{t}}=\frac{1}{k_{2} q_{e}^{2}}+\frac{t}{q_{e}} \\
& \mathrm{q}_{\mathrm{t}}=\mathrm{k}_{\mathrm{id}}(\mathrm{t})^{0,5}+\mathrm{D}
\end{aligned}
$$


Where $\mathrm{q}_{\mathrm{e}}$ is the adsorptive capacity at the saturation point in $\mathrm{mg} \cdot \mathrm{g}^{-1}$, qt the adsorptive capacity varying in time in $\mathrm{mg} \cdot \mathrm{g}^{-1}, \mathrm{~K}_{1}$ and $\mathrm{K}_{2}$ are the speed constants of the pseudo-first and pseudo-second order models in min-1 e g mg-1 min-1, respectively, Kid is the intraparticle diffusion constant in $\mathrm{mg} \cdot \mathrm{g}^{-1} \cdot \mathrm{min}^{-0.5}$, D the constant related to the thickness of the diffusion layer in $\mathrm{mg} \cdot \mathrm{g}^{-1}$ and the contact time between species in minutes.

\subsubsection{Balance study and determination of thermodynamic parameters}

The adsorption isotherms represent a balance between the concentration of dye in the liquid phase and the amount of dye present in the adsorbent [28,29]. All equilibrium tests were performed in triplicate, the conditions used were: $0.5 \mathrm{~g}$ of adsorbent, $150 \mathrm{rpm}$ for $12 \mathrm{~h}$ and $\mathrm{pH} 3.5$, in different concentrations of the dye solution $\left(25,35,45,55\right.$ and $\left.65 \mathrm{mg} \mathrm{L}^{-1}\right)$ and different temperatures (30, 40,60 and $100 \pm 2{ }^{\circ} \mathrm{C}$ ). The models used were Langmuir and Freundlich according to linearized Equations 8, 9 and 10 [25, 28-31].

$$
\begin{aligned}
& \frac{C_{e}}{q_{e}}=\frac{1}{b q_{m}}+\frac{C_{e}}{q_{m}} \\
& R_{L}=\frac{1}{1+b C_{0}} \\
& \operatorname{Ln}\left(q_{e}\right)=\operatorname{Ln}\left(K_{F}\right)+\frac{1}{\mathrm{n}} \operatorname{Ln}\left(C_{e}\right)
\end{aligned}
$$

Where: $\mathrm{q}_{\mathrm{e}}$ is the adsorptive capacity at the saturation point in $\mathrm{mg} \cdot \mathrm{g}^{-1}, \mathrm{C}_{\mathrm{e}}$ is the residual concentration in equilibrium $\left(\mathrm{mg} \cdot \mathrm{L}^{-1}\right), \mathrm{C}_{\mathrm{o}}$ is the concentration at the beginning $\left(\mathrm{mg} \cdot \mathrm{L}^{-1}\right), \mathrm{b}\left(\mathrm{L} \cdot \mathrm{mg}^{-1}\right)$ and $\mathrm{q}_{\mathrm{m}}$ represent the Langmuir constants and the adsorption capacity and energy $\left(\mathrm{mg} \cdot \mathrm{g}^{-1}\right), \mathrm{K}_{\mathrm{f}}$ the Freundlich constant. and $\mathrm{R}_{\mathrm{L}}$ is the separation factor (dimensionless). The value of $\mathrm{R}_{\mathrm{L}}$ indicates whether the adsorption is irreversible $\left(\mathrm{R}_{\mathrm{L}}=0\right)$, favorable equilibrium $\left(0<\mathrm{R}_{\mathrm{L}}<1\right)$.

The thermodynamic characteristics of the process were expressed at different temperatures and concentrations. Through linearized Equations 11, 12 and 13 it is possible to determine the variations of entropy, enthalpy, Gibbs free energy and activation energy of the adsorptive process [25, 28, 29, 32].

$$
\begin{aligned}
& \operatorname{Ln}(K)=\frac{-\Delta \mathrm{H}^{\circ}}{\mathrm{RT}}+\frac{\Delta \mathrm{S}^{\circ}}{\mathrm{R}} \\
& \Delta \mathrm{G}^{\circ}=-\mathrm{nRT} \operatorname{Ln}(\mathrm{K}) \\
& \operatorname{Ln}(K C)=-\frac{\mathrm{Ea}}{\mathrm{RT}}+\operatorname{Ln} \mathrm{A}
\end{aligned}
$$

Where: $\mathrm{K}$ is the thermodynamic equilibrium constant $\left(\mathrm{L} \cdot \mathrm{g}^{-1}\right), \mathrm{Kc}$ is the kinetic constant of the thermodynamic equilibrium $\Delta \mathrm{H}^{\circ}, \Delta \mathrm{S}^{\circ}$ and $\Delta \mathrm{G}^{\circ}$ refer to enthalpy, entropy and Gibbs free energy of the system, respectively. $\mathrm{R}$ is the universal gas constant $\left(8.314 \mathrm{~J} \mathrm{~mol}^{-1} \cdot \mathrm{K}^{-1}\right), \mathrm{T}$ is the temperature (K), Ea corresponds to activation energy and $\mathrm{A}$ is the Arrhenius frequency factor.

\subsection{Cytotoxicity assays in animals and microbials cells}

The water obtained after treatment, to be discarded in the environment, cannot cause damage to microbiota or animals [25]. The residual water for cytotoxicity assays for both cells, animal and microbial, was used in the best experimental condition (dye concentration $25 \mathrm{mg} \cdot \mathrm{L}^{-1}, 150 \mathrm{rpm}$ at $30{ }^{\circ} \mathrm{C}, 0.5 \mathrm{~g}$ of adsorbent and $\mathrm{pH} 3.5$ ). This water was neutralized in order to decrease toxicity to cells and the environment when this effluent is discarded. 
The cytotoxicity assay in J774 macrophage cells was performed according to Souza et al. (2014) [33] with few modifications. The cells were grown in 96 well plates at a concentration of $6 \times 10^{5}$ cells / well and incubated in a $5 \% \mathrm{CO}_{2}$ oven at $37^{\circ} \mathrm{C}$ for $24 \mathrm{~h}$ (to adapt the cells to the wells surface). After this incubation period, the supernatant was removed and $100 \mu \mathrm{L}$ of the neutralized residual water was added to the cells in RPMI medium and again the system was incubated in a $5 \% \mathrm{CO}_{2}$ oven at $37{ }^{\circ} \mathrm{C}$ for 48 hours. After this step, the supernatant was removed and to the wells RPMI medium without phenol red plus $10 \mu \mathrm{L}$ of 3- (4,5-dimethyltriazol-2-yl) -2,5-diphenyltetrazolium (MTT) $0.5 \mathrm{mg} \mathrm{mL}^{-1}$.

The plates were incubated for an additional 3 hours to allow MTT to react with the cells and form the insoluble crystals of Formazan. After 3 hours, Formazan crystals were dissolved in DMSO and immediately after the absorbance of the system, it was determined in an ELISA Benchmark Plus plate reader (Bio-Rad) at $490 \mathrm{~nm}$.

In the supernatants of macrophage cultures, the nitric oxide content was determined by the colorimetric method of Griess [34]. The nitric oxide concentration was estimated using a standard curve (3.12-100 $\left.\mu \mathrm{mol} \cdot \mathrm{mL}^{-1}\right)$. The reading was performed on a spectrophotometer (Bio-Rad 3550, Hercules, CA) at $595 \mathrm{~nm}$. This experiment was carried out in order to confirm whether the water used had a toxic effect.

For the microbial growth viability assays, the following strains Escherichia coli, Pseudomonas aeruginosa, Enterococcus faecalis and Staphylococcus aureus were used, maintained in MuellerHinton (MH) agar culture medium. These belong to the collection of microorganisms of the Industrial Microbiology Laboratory located in the Department of Chemical Engineering of the Federal University of Pernambuco. These cultures were inoculated in $\mathrm{MH}$ broth at $35{ }^{\circ} \mathrm{C}$ for 18 hours. Then, a $0.1 \mathrm{~mL}$ aliquot was transferred to another tube containing Mueller-Hinton broth and incubated for 3 hours at $35{ }^{\circ} \mathrm{C}$. Thus, obtaining a suspension calibrated with the tube 0.5 of the MacFarland scale that corresponds to $10^{8} \mathrm{UFC} \cdot \mathrm{mL}^{-1}$. Subsequently, with the aid of a swab, sowing was carried out in plates containing $\mathrm{MH}$ agar. Once this was done, $10 \mu \mathrm{L}$ of the neutralized residual water was inoculated to the plates containing the culture medium, and then incubated at $35{ }^{\circ} \mathrm{C}$ for 24 hours, in order to check whether the residual water would cause cell death. All tests were performed under aseptic conditions.

\section{RESULTS AND DISCUSSION}

\subsection{Physical and chemical characterization}

The bacterial cellulose presented dry weight $0.34 \pm 0.01 \mathrm{~g}$, wet mass $5.43 \pm 0.01 \mathrm{~g}$, ashes of $0.005 \pm 0,0 \%$ and humidity of $92 \%$. These results are close to those obtained by Mikkelsen et al. (2009) [35], Lopes et al. (2014) [36], Salari et al. (2019) [37] and Gayathri and Srinikethan (2019) [38] characterizing bacterial cellulose. Figure 3 shows the results of the FTIR, DRX, TGA/DTG and PCZ analyzes.

The Figure 3A shows the FTIR spectrum for bacterial cellulose. This was analyzed according to the data obtained by Cheng et al. (2019) [39], Zhuang and Wang (2019) [40] and Bagewadi et al. (2020) [41]. The spectrum showed bands attributed to $\beta$-glycosidic bonds between glucose units at $896 \mathrm{~cm}^{-1}$, symmetrical stretching of primary alcohol (C-O) and anti-symmetric elongation of C$\mathrm{O}-\mathrm{C}$ bridges in the 1040 and $1168 \mathrm{~cm}^{-1}$ regions, respectively. The $\mathrm{C}-\mathrm{H}$ deformation $\left(\mathrm{CH}_{3}\right.$ or S-H in the flexion plane) in $1340 \mathrm{~cm}^{-1}$. One band at $1400 \mathrm{~cm}^{-1}$ related to the curvature of $\mathrm{CH}_{2}$ and $\mathrm{OH}$. Other bands are related to the $\mathrm{H}-\mathrm{O}-\mathrm{H}$ flexion related to the water adsorbed to the structure (1650 $\left.\mathrm{cm}^{-1}\right)$. Extension of the $\mathrm{CH}, \mathrm{CH}_{2}$ and $\mathrm{CH}_{3}$ groups at $2889 \mathrm{~cm}^{-1}$ and $\mathrm{OH}$ extension represented by the broadband at $3348 \mathrm{~cm}^{-1}$.

In the X-ray diffractogram (Figure 3B), the bacterial cellulose produced is a semicrystalline material with crystalline and amorphous regions. The two predominant peaks found in the analyzes make it possible to assess the presence of type I and II cellulose. In X-ray analysis, cellulose type I is characterized by peaks of $18^{\circ} \leq 2 \theta \leq 19^{\circ}$ in the amorphous region and $22^{\circ} \leq 2 \theta \leq 23^{\circ}$ in the crystalline region. Type II cellulose shows peaks of $13^{\circ} \leq 2 \theta \leq 15^{\circ}$ in the amorphous region and 
$18^{\circ} \leq 2 \theta \leq 22^{\circ}$ in the crystalline region. The presence of cellulose type I and II is characteristic of bacterial cellulose, while the vegetable cellulose presents only type I cellulose [42, 43].

Through the Equations proposed Lopes et al. (2014) [36] and Salari et al. (2019) [37] it was possible to determine the cellulose crystallite width $41 \pm 0.5(\AA)$ and the crystallinity index of $76 \pm$ $0.2 \%$. These results are close to those obtained by Lopes et al. (2014) (36), Salari et al. (2019) [37] and Gayathri and Srinikethan (2019) [38] studying different bacterial celluloses.

The analyzes by thermogravimetry (TGA) and Derivative Thermogravimetry (DTG) (Figure 3C) show the variation in mass of a sample as a function of temperature. The cellulose obtained had three different stages of mass loss. During an initial phase in the ambient temperature ranges up to approximately $100{ }^{\circ} \mathrm{C}$ - there is a small loss of mass related to the evaporation of the residual water molecules (from the drying process) physically adsorbed by hydrogen bonds to the sample surface. A second phase, from $220^{\circ} \mathrm{C}$ to $420^{\circ} \mathrm{C}$, where the samples suffer a marked loss of mass, which can be explained by combustion with consequent degradation of cellulose, this step extends to the region of $420{ }^{\circ} \mathrm{C}$ up to $700{ }^{\circ} \mathrm{C}$, finally, the third and last phase shows the thermo-oxidative degradation of cellulose. The DTG curve shows the maximum cellulose degradation around 350 ${ }^{\circ} \mathrm{C}$. This degradation profile is similar to those obtained by Kiziltas et al. (2015) [44], Vasconcelos et al. (2017) [45] and Sousa et al. (2020) [46].

The Figure 3D shows the relationship between the initial $\mathrm{pH}$ and the end of the solutions. From it, it is possible to determine the zero-load point by making an arithmetic average of the points where the final $\mathrm{pH}$ remains constant. Through the analysis of Figure 3D, it is observed that the PCZ is 6.8. Thus, based on the graph, it can be predicted that below these values of the $\mathrm{pH}$ of the PCZ the adsorbent has a positive surface charge favoring the adsorption of negatively charged adsorbates and above the $\mathrm{pH}$ of the PCZ the surface is negatively charged, favoring the adsorption of loaded adsorbates positively. Close values were found by Silva et al. (2018) [23] and Hassan et al. (2019) [24] for different celluloses.
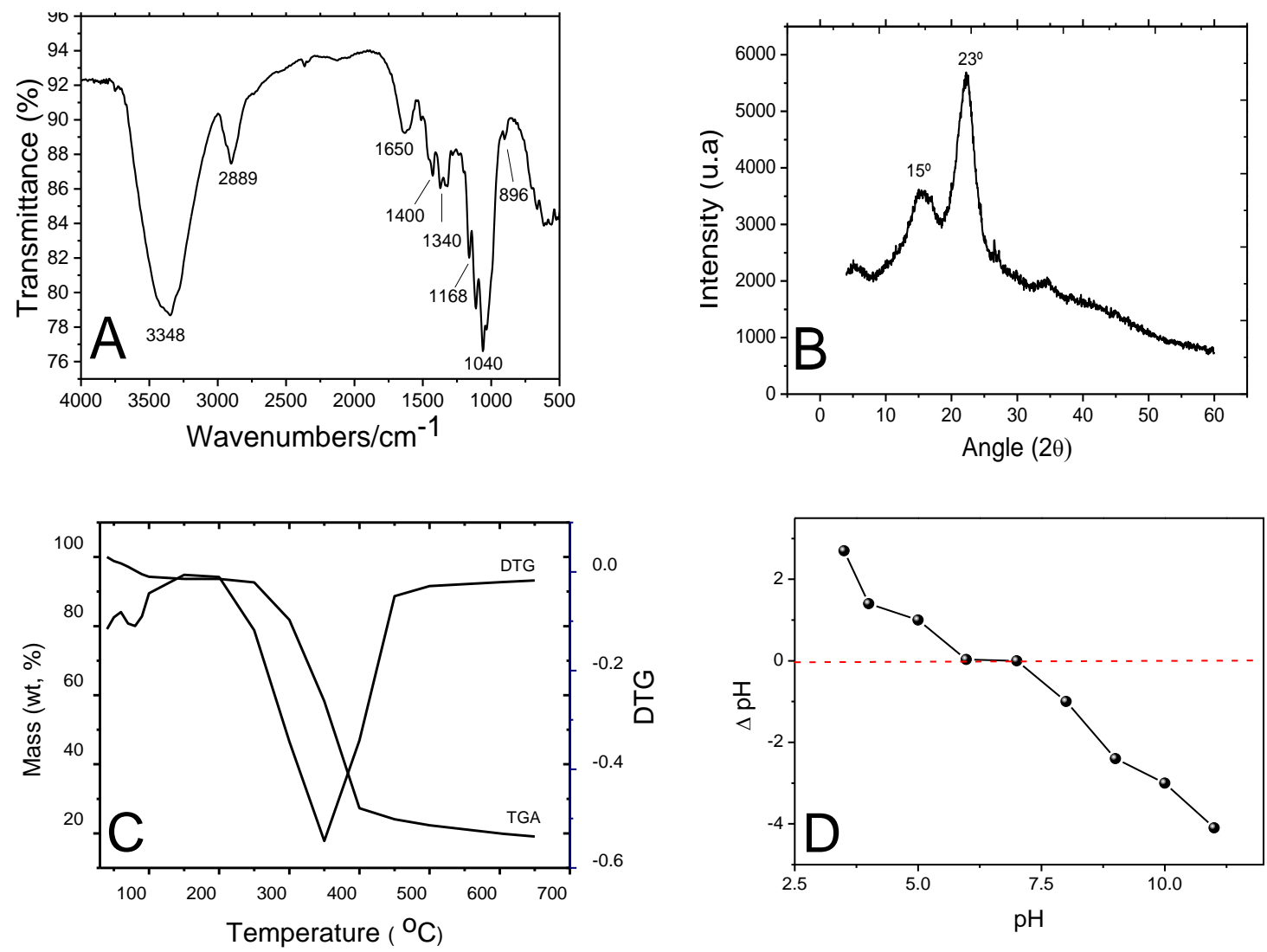

Figure 3. Physico-chemical characterization for FTIR (A), DRX (B), TGA / DTGC (C) and PCZ (D) of bacterial cellulose produced by Gluconacetobacter hansenii in modified HS culture medium with molasses carbon source. 


\subsection{Adsorption assays}

\subsubsection{Influence of ph on the adsorption capacity of bacterial cellulose}

In the adsorption process, factors such as the properties of the adsorbent and adsorbate, temperature and $\mathrm{pH}$ of the solution can directly influence the efficiency of the process [47-49]. The $\mathrm{pH}$ determines the intensity of the electrostatic interactions between adsorbent and adsorbate [47, 49].

The adsorption mechanisms involving materials of biological origin are not yet fully understood, as they involve several processes of capture of the adsorptive species. In general, it is accepted that the surface of an adsorbent has an important role in the mechanism of capture of chemical species $[47,49]$. These mechanisms, in general, involve surface groups that in an aqueous medium can act in the capture and retention of ionic or molecular species. Such groups can be modified in an aqueous medium by varying the $\mathrm{pH}$, which affects the adsorption process [48]. Figure 4 shows the profile of the bacterial cellulose adsorption capacity as a function of $\mathrm{pH}$.

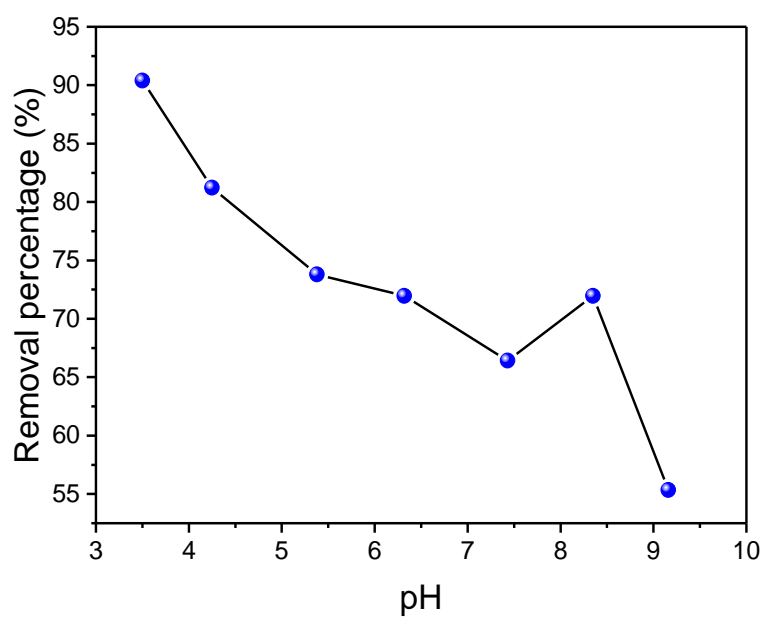

Figure 4. Influence of $p H$ in the adsorptive process bacterial cellulose and RBB.

The highest values of dye removal are observed at low $\mathrm{pH}$ values, this is explained by the fact that the molecules of the RBB anionic dye are negatively charged in aqueous solution [47, 48], while cellulose adsorption sites at a lower $\mathrm{pH}$ have increased the number of positive charges [30, 31, 47, 48]. Cellulose has hydroxyl functional groups which, under acidic conditions, are protonated, enabling the interaction between the different adsorbent and adsorbent charges. Cellulose acquires a positive charge that, by electrostatic attraction, binds to negatively charged dyes $[30,31,47]$. In order to prove this behavior on the surface of cellulose as a function of $\mathrm{pH}$, a preliminary study of the acid-base behavior of the surface of these adsorbents in an aqueous medium was carried out by determining the PCZ $[23,24]$ as shown in Figure 3D.

\subsubsection{Kinetic modeling of the adsorptive process}

The kinetic study of adsorption of dyes on adsorbent materials is a prerequisite for choosing the best removal conditions [27]. This evaluates the adsorbent adsorption rate and controls the residence time of the adsorbate at the solution interface [50, 51]. The Figure 5 shows the kinetic evolution of the Remazol Black B dye removal process in contact with the adsorbent. This experiment was carried out in batch tests at temperatures of $30,40,60$ and $100 \pm 2{ }^{\circ} \mathrm{C}$ for a period of 120 minutes. And the adsorptive capacities in the respective times were calculated using Equation 4. 


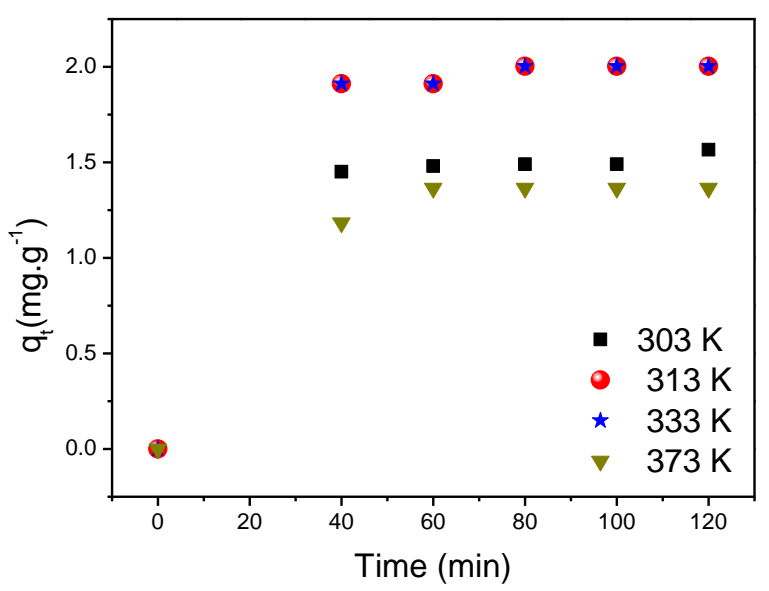

Figure 5. Kinetic profile for adsorption of RBB dye by bacterial cellulose (pH 3.5; 304060 and $100{ }^{\circ} \mathrm{C} \pm 2$ $\left.{ }^{\circ} \mathrm{C} ; 150 \mathrm{rpm}\right)$.

It can be seen through Figure 5, that the process reaches equilibrium around 80 minutes for all temperatures studied. This fact is probably related to the high number of adsorption sites available on the surface of the material [49]. Thus, as time increases, saturation of the available surface area occurs and thus the equilibrium situation is achieved and no significant change in the amount of adsorbed dye can then be perceived [29]. The rapid removal of adsorbate and the achievement of equilibrium in a short period is one of the indications of a good adsorbent material [50,51].

The kinetics experiments, in addition to finding the time in which the adsorption equilibrium occurs (Figure 5), aimed to assess the stage that controls the adsorption process [50, 51]. Thus, three linearized kinetic models were tested to fit the experimental data, namely, the pseudo-first order model (Figure 6A), pseudo-second order model (Figure 6B) and intraparticle diffusion (Figure 6C).
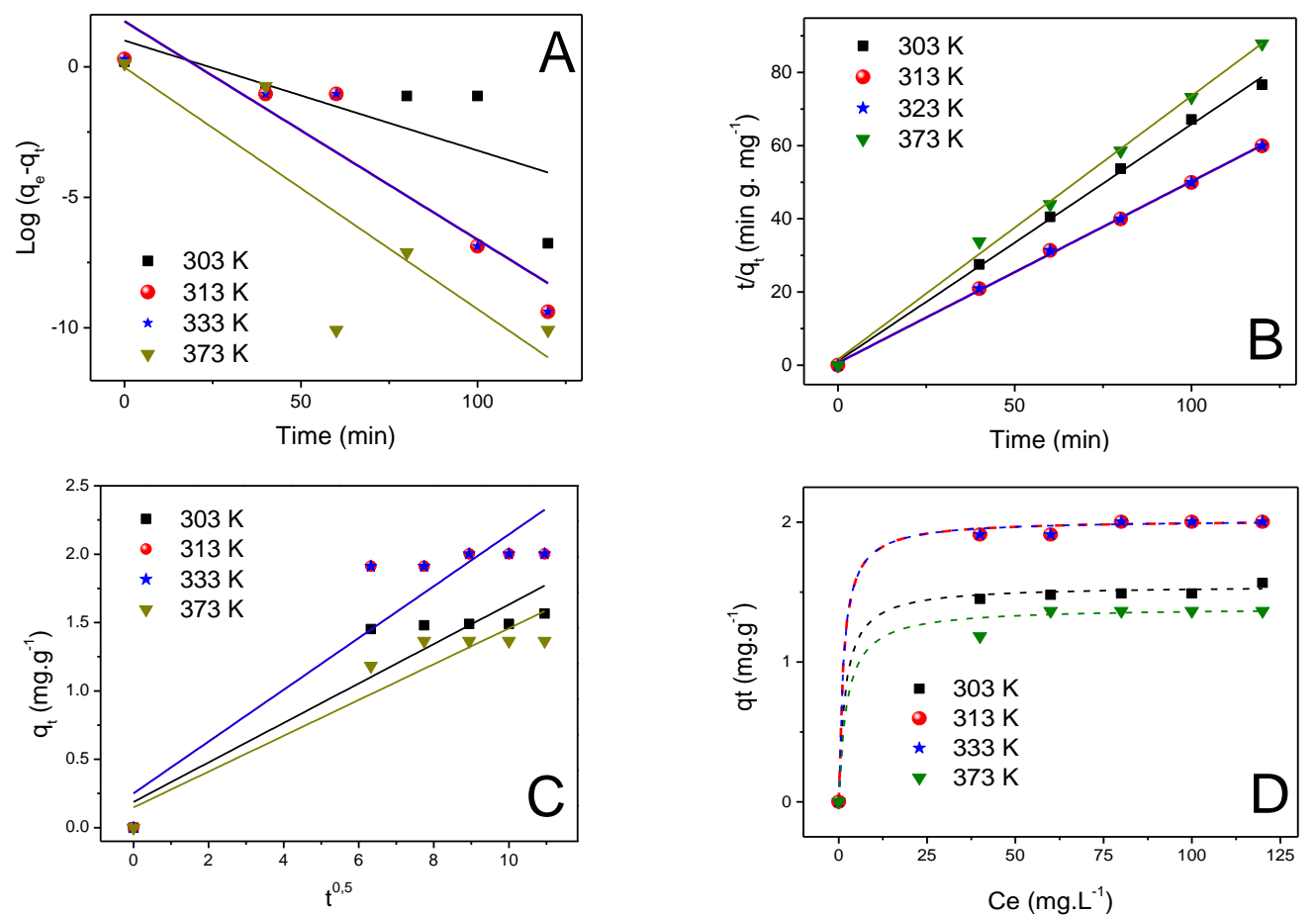

Figure 6. Linearization of pseudo-first order models (A), pseudo-second order models (B), Morris-Webber (C) and the linear fit between the experimental and theoretical data of the pseudo second order model. 
The Tables 1, 2 and 3 show the results of the constants for each model and the respective correlation coefficients, that is, how the theoretical model fits the experimental data (Figure 6D). A good correlation of kinetic data proves the possible kinetic mechanism of adsorption in the solid phase $[50,51]$.

Table 1. Parameters of pseudo-first order kinetics.

\begin{tabular}{|c|c|c|c|c|}
\hline \multirow{3}{*}{$\mathbf{T}(\mathbf{K})$} & \multicolumn{4}{|c|}{ Pseudo-first-order } \\
\hline & \multicolumn{4}{|c|}{$\log \left(q_{e}-q_{t}\right)=\log \left(q_{e}\right)-\frac{k_{1}}{2,303} t$} \\
\hline & $\mathbf{k}_{1}\left(\min ^{-1}\right)$ & $\mathbf{R}^{2}$ & $\begin{array}{c}\text { qe, expe } \\
\left(\mathbf{m g} \cdot \mathbf{g}^{-1}\right)\end{array}$ & $q_{e, \text { theoretical }}\left(\mathrm{mg} \cdot \mathrm{g}^{-1}\right)$ \\
\hline 303 & 0.097 & 0.42304 & 1.566 & 10.248 \\
\hline 313 & 0.192 & 0.84112 & 2.002 & 55.889 \\
\hline 333 & 0.192 & 0.84112 & 2.002 & 55.889 \\
\hline 373 & 0.213 & 0.58979 & 1.365 & 0.950 \\
\hline
\end{tabular}

Table 2. Parameters of pseudo-second order kinetics.

\begin{tabular}{|c|c|c|c|c|}
\hline \multirow{3}{*}{$\mathbf{T}(\mathbf{K})$} & \multicolumn{4}{|c|}{ Pseudo-second-order } \\
\hline & \multicolumn{4}{|c|}{$\frac{t}{q_{t}}=\frac{1}{k_{2} q_{e}^{2}}+\frac{t}{q_{e}}$} \\
\hline & $k_{2}\left(g \cdot g^{-1} \min ^{-1}\right)$ & $\mathbf{R}^{2}$ & $\underset{\left(\text { mg.g }^{-1}\right)}{\mathbf{q}, \text { exp }}$ & $\begin{array}{l}\text { Qe, theoretical } \\
\left(\text { mg.g }^{-1}\right)\end{array}$ \\
\hline 303 & 0.362 & 0.99715 & 1.566 & 1.546 \\
\hline 313 & 0.380 & 0.99898 & 2.002 & 2.017 \\
\hline 333 & 0.380 & 0.99898 & 2.002 & 2.017 \\
\hline 373 & 0.321 & 0.99603 & 1.365 & 1.389 \\
\hline
\end{tabular}

Table 3. Morris-Webber kinetics parameters.

\begin{tabular}{|c|c|c|c|}
\hline \multirow[t]{2}{*}{$\mathbf{T}(\mathbf{K})$} & \multicolumn{3}{|c|}{$\begin{array}{c}\text { Morris-Weber } \\
\mathbf{q}_{t}=\mathbf{k}_{\mathrm{id}}(\mathbf{t})^{0,5}+\mathrm{D}\end{array}$} \\
\hline & $K_{\text {id }}\left(\min ^{-1}\right)$ & D $\left(\mathrm{mg} \mathrm{g}^{-1}\right)$ & $\mathbf{R}^{2}$ \\
\hline 303 & 0.144 & 0.188 & 0.8336 \\
\hline 313 & 0.189 & 0.250 & 0.82881 \\
\hline 333 & 0.189 & 0.250 & 0.82881 \\
\hline 373 & 0.131 & 0.147 & 0.86336 \\
\hline
\end{tabular}

Through the correlation coefficient, it was found that the pseudo-second order model obtained a good adjustment to the experimental data obtained for bacterial cellulose, since they approach the theoretical $\mathrm{q}_{\mathrm{e}}$ values (Figure 5B). This model consists of the adsorption capacity of the solid phase and reports the behavior of the process over the entire contact time range [49, 51].

The models of pseudo-first order (applied in times above the initial 20-30 minutes of the adsorption process) and intraparticle diffusion (mechanism as a limiting step) did not fit satisfactorily with the experimental data because they have a low correlation coefficient $[52,53]$. 
Other authors carried out the evaluation of the removal of the RBB dye and observed that the capture of this dye also adjusted to the pseudo-second model, as observed by Alves et al. (2020) [29] using soil samples, Cruz Filho et al. (2016) [48] using mixed biomass and Ziapour et al. (2016) [54] using bagasse.

\subsubsection{Balance study and thermodynamic parameters}

The adsorption isotherm is fundamental for understanding the adsorption mechanism [55]. An adsorption isotherm shows the amount of a particular solute adsorbed to an adsorbent surface, depending on the equilibrium concentration of the solute [56]. The adsorption isotherms indicate how the adsorbent will remove the contaminating molecules and whether the desired purification can be obtained, as well as presenting a maximum estimate of the adsorption capacity [57]. The most used models for balance study are those of Langmuir and Freundlich

The Langmuir model assumes a monolayer and considers the adsorbent surface with identical sites in terms of energy, that is, it considers the adsorbent surface to be homogeneous $[55,56]$. The Freundlich model describes multilayer adsorption systems and is applied to the heterogeneous surface, where the adsorption sites are considered to have different adsorption energies, which vary according to the surface coverage [55-57]. The Figure 7 shows the linearization of data for Langmuir (Figures 7A e 7C) and Freundlich (Figure 7B e 7D) models. All experiments were conducted in batches until the equilibrium time obtained by the kinetic tests and the equilibrium tests of the bacterial cellulose adsorbent with the RBB adsorbate were carried out at different temperatures.
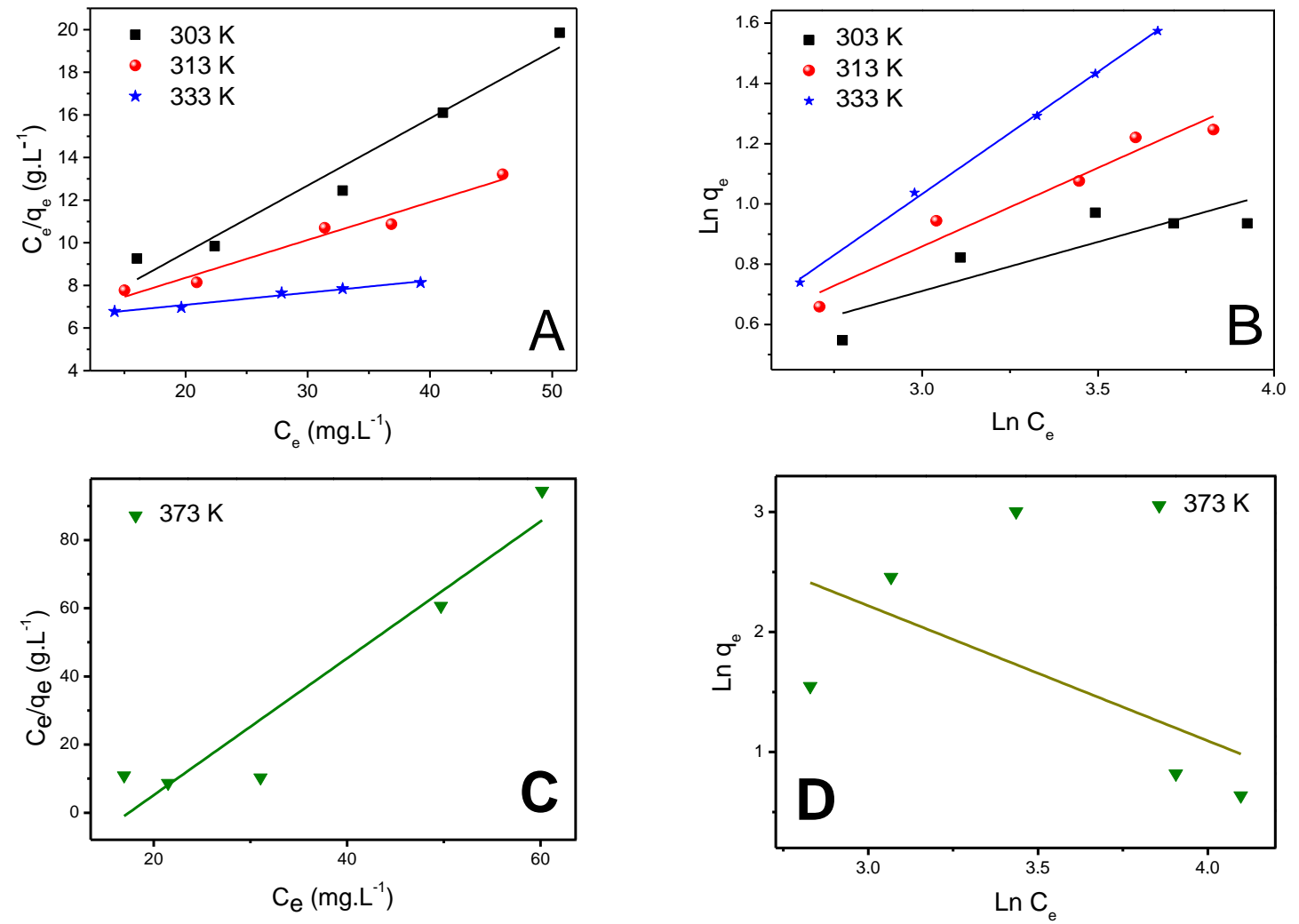

Figure 7. Langmuir $(A e C)$ and Freundlich $(B$ e D) isotherms in their linearized form and the linear fit between the experimental data and the Langmuir theoretical model.

The values of the linearization parameters of the Langmuir and Freundlich models are shown in Table 4 . Where $\mathrm{q}_{\mathrm{m}}$ corresponds to the maximum adsorption capacity and $\mathrm{K}_{\mathrm{L}}$ refers to the Langmuir 
adsorption constant, $\mathrm{n}$ represents the degree of heterogeneity of the Freundlich surface, $\mathrm{K}_{\mathrm{F}}$ corresponds to the Freundlich adsorption constant and $\mathrm{R}^{2}$ corresponds to the correlation coefficient between the experimental data and the theoretical model.

Table 4. Linearization of experimental data for the adsorption of RBB by bacterial cellulose according to the Langmuir and Freundlich isotherm models.

\begin{tabular}{|c|c|c|c|c|c|c|}
\hline \multirow[b]{2}{*}{$\mathbf{T}(\mathbf{K})$} & \multicolumn{3}{|c|}{ Langmuir } & \multicolumn{3}{|c|}{ Freundlich } \\
\hline & & $=\frac{1}{b q_{m}}+\frac{C_{e}}{\boldsymbol{q}_{m}}$ & & $\operatorname{Ln}\left(\boldsymbol{q}_{e}\right)$ & $\ln \left(K_{F}\right)$ & $\operatorname{Ln}\left(C_{e}\right)$ \\
\hline & b $\left(\mathbf{L} \cdot \mathrm{mg}^{-1}\right)$ & $q_{m}\left(m \cdot g^{-1}\right)$ & $\mathbf{R}^{2}$ & $q_{m}\left(m \cdot g^{-1}\right)$ & $\mathrm{n}^{-1}$ & $\mathbf{R}^{2}$ \\
\hline 303 & 0.096 & 3.178 & 0.951 & 0.765 & 3.065 & 0.67447 \\
\hline 313 & 0.036 & 5.630 & 0.959 & 0.492 & 1.9150 & 0.93923 \\
\hline 333 & 0.009 & 17.513 & 0.973 & 0.246 & 1.232 & 0.99795 \\
\hline 373 & -0.057 & 0.498 & 0.8847 & 269.662 & -0.888 & 0.13228 \\
\hline
\end{tabular}

The results of the adjustments showed that the Langmuir model presented better correlation coefficients when compared to the Freundlich model. According to the Langmuir model, maximum adsorption occurs in a monolayer of solute molecules on the surface of the adsorbent, without any lateral interaction between the adsorbed molecules $[52,53,58]$. That is, the adsorbent has a limited number of positions available on the surface and that the molecules can be adsorbed until the available surface sites are vacated $[49,51]$. Thus, it is considered that the molecules were adsorbed only on free sites $[55,56]$. The effect of temperature is a significant physical-chemical parameter in the adsorptive process $[59,60]$. In general, adsorption increases with increasing temperature [61]. This fact is related to the increase in the molecular solubility of the dye and also to its chemical potential [59]. The increase in temperature promotes an increase in the molecular diffusivity of the dye and, consequently, by an increase in the adsorption speed. In addition to the increased mobility of the dye molecules, there is an increase in the number of active adsorption sites, due to the swelling of the material's pores [59-61]. However, at high temperatures $\left(100^{\circ} \mathrm{C}\right)$ there is a decrease in the adsorption capacity, and this is because the increase in the process temperature can damage its surface of natural adsorbents and indicates that at this temperature the process is not favorable $[48,62]$.

This behavior is also confirmed through the data obtained in Figure 8, which show that at temperatures below $100^{\circ} \mathrm{C}$ the process is favorable, because the value of the constant $\mathrm{R}_{\mathrm{L}}$ is between 0 and 1 (Figure 8A) [30]. Figure 8B shows that at temperatures above $100^{\circ} \mathrm{C}$ the adsorptive process is unfavorable.
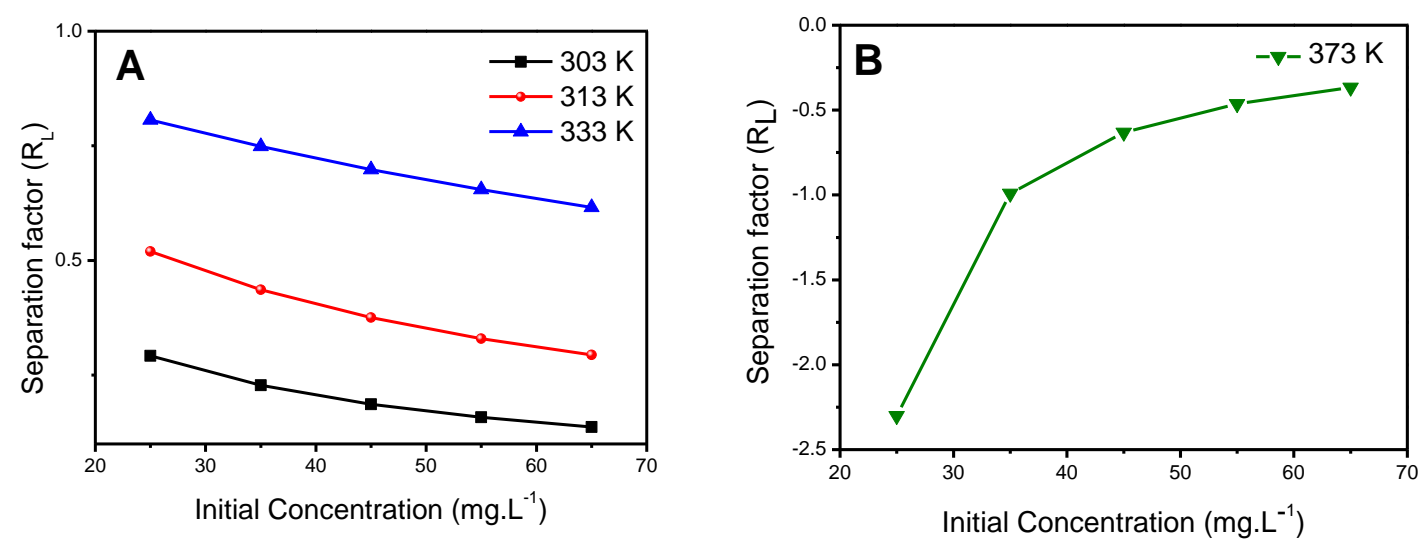

Figure $8 . R_{L}$ values for the adsorption of the $R B B$ dye. 
Through the results obtained in the kinetic and equilibrium studies it was possible to make a comparison with different natural adsorbents. Table 5 shows the type of adsorbent, the maximum adsorption capacity (Qo), equilibrium time and models that were adjusted, both in the kinetic study and in the equilibrium.

According to Table 5, the adsorbent capacity of the adsorbent from bacterial cellulose is lower when compared to activated carbon from fungus residue, chitosan, fiber composed of polyethyleneimine-polyvinyl chloride and activated carbon. And it has greater adsorption capacity when compared to mixed biomass of Aspergillus niger/elephant grass, green coconut mesocarp, macadamia seed husks, Eichhornia crassipes/chitosan composite. These differences in the adsorption efficiency are directly related to the nature of the adsorbent and the process conditions [31].

Table 5. Comparison of the adsorption capacity of reactive dyes in various adsorbents.

\begin{tabular}{|c|c|c|c|c|c|}
\hline Adsorber & $\begin{array}{c}\text { Qo (mg.g- } \\
\text { 1) }\end{array}$ & $\begin{array}{l}\text { Time } \\
(\text { min) }\end{array}$ & Kinetic model & isotherms & References \\
\hline Bacterial cellulose & 17.51 & 80 & Pseudo-second & Langmuir & This work \\
\hline $\begin{array}{l}\text { Eichhornia crassipes / } \\
\text { chitosan composite }\end{array}$ & 0.606 & 60 & Pseudo-second & Langmuir & [63] \\
\hline Macadamia seed husks & 1.12 & 600 & Pseudo-second & Freundlich & [64] \\
\hline $\begin{array}{l}\text { Aspergillus niger / } \\
\text { elephant grass }\end{array}$ & 9.645 & 40 & Pseudo-second & Langmuir & [25] \\
\hline $\begin{array}{l}\text { Activated carbon from } \\
\text { fungus residue }\end{array}$ & 19.6 & - & - & Langmuir & [65] \\
\hline $\begin{array}{l}\text { Activated carbon } \\
\text { derived from coconut } \\
\text { shell }\end{array}$ & 95 & 390 & - & $\begin{array}{l}\text { Langmuir, } \\
\text { Freundlich and } \\
\text { Radke- } \\
\text { Prausnitz }\end{array}$ & [66] \\
\hline Chitosan & 130 & 60 & $\begin{array}{l}\text { Pseudo-first e second } \\
\text { order and intraparticle } \\
\text { diffusion }\end{array}$ & $\begin{array}{l}\text { Langmuir and } \\
\text { Freundlich }\end{array}$ & [67] \\
\hline $\begin{array}{l}\text { Fiber composed of } \\
\text { polyethyleneimine- } \\
\text { polyvinyl chloride }\end{array}$ & 314.4 & 360 & Pseudo-second & Langmuir & [68] \\
\hline Activated charcoal & 434 & 60 & - & Langmuir & [69] \\
\hline
\end{tabular}

The determined thermodynamic parameters were Gibbs free energy $\left(\Delta G^{\circ}\right)$, enthalpy variation $\left(\Delta H^{\circ}\right)$ and entropy $\left(\Delta S^{\circ}\right)$, the same being of great importance for the adsorption process [25, 70]. The estimates of the thermodynamic parameters $\Delta \mathrm{S}^{\circ}$ and $\Delta \mathrm{H}^{\circ}$ were possible to determine by linear regression $\mathrm{Ln}(\mathrm{K})$ as a function of $\mathrm{T}^{-1}$ as shown in Figure 9 [32, 70]. The temperature of $100{ }^{\circ} \mathrm{C}$ was not used to obtain the thermodynamic parameters because it showed a decrease in the adsorption capacity. Table 6 shows the obtained thermodynamic parameters. 


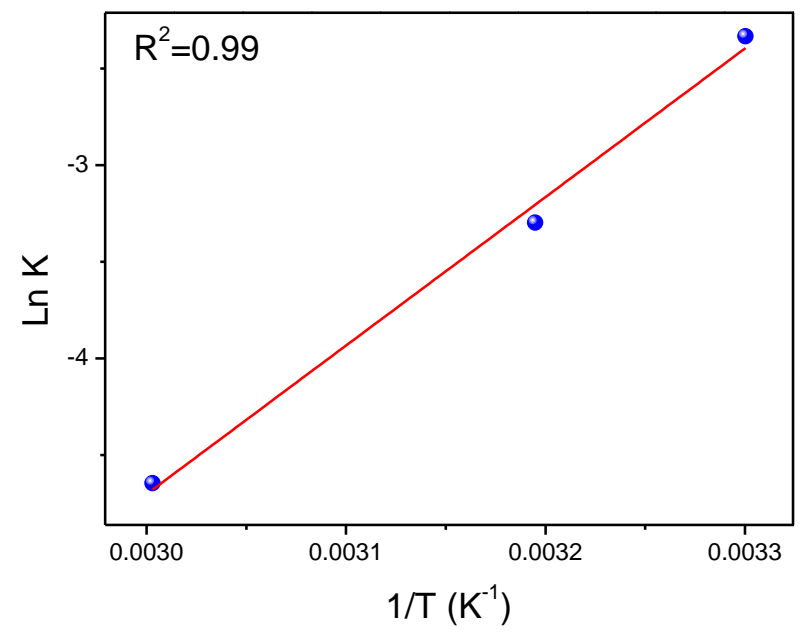

Figure 9. Variation of the Langmuir Kl equilibrium constant with the absolute temperature for the adsorption process of the RBB dye in bacterial cellulose.

Table 6. Thermodynamic parameters for RBB adsorption on bacterial cellulose

\begin{tabular}{|c|c|c|c|c|}
\hline $\mathbf{T}(\mathbf{K})$ & $K_{L}\left(L \cdot m^{-1}\right)$ & $\Delta G^{\circ}\left(k^{\prime} . m o l^{-1}\right)$ & $\Delta H^{\circ}\left(k^{\prime} . m o l^{-1}\right)$ & $\Delta \mathrm{S}^{\circ}\left(\mathrm{J} \mathrm{mol}^{-1}\right)$ \\
\hline 303 & 0.096 & +5.88 & -1.03 & -2.89 \\
\hline 313 & 0.036 & +8.58 & & \\
\hline 333 & 0.009 & +12.75 & & \\
\hline
\end{tabular}

From the data in Table 6, it can be seen that Gibbs free energy has positive values, indicating that the reverse reaction is negative, it also demonstrates that the process is non-spontaneous and can be reversible, therefore, the cellulose can be recovered. for reuse [71, 72].

The negative enthalpy value suggests an exothermic nature of adsorption and this is accompanied by an energy release $[25,70]$. The value of $\Delta H^{\circ}$ gives an indication of the type of adsorption that occurs, the two main types being physical adsorption (physisorption) and chemical adsorption (chemisorption). In physisorption, the adsorption heat has values less than $20.9 \mathrm{~kJ} \cdot \mathrm{mol}^{-}$ ${ }^{1}$ and in chemisorption, the adsorption heat has energy values greater than $20.9 \mathrm{~kJ} \mathrm{~mol}^{-1}$ [73]. Therefore, the value of $\Delta H^{\circ}$ for the adsorption of the RBB dye indicates that the adsorption process is of a physical nature.

Negative entropy values indicate an increase in the degree of organization of the system, associated with the accommodation of the dye on the cellulose surface, also indicating that there is no increase in mobility and there is no dissociation of the dye particles on the cellulose surface [25, $71,72]$.

The activation energy was extrapolated using the Arrhenius equation and Figure 10 shows the Arrhenius graph of $\mathrm{Ln} \mathrm{K}$ versus $1 / \mathrm{T}$ where $\mathrm{K}$ was obtained from the pseudo second order model. The calculated $\mathrm{E}_{\mathrm{a}}$ value was $23.8 \mathrm{~kJ} \cdot \mathrm{mol}^{-1}$ and the exponential factor of the Arrhenius constant 1.65. This means that for the adsorbate interaction to occur with the cellulose surface, it is necessary to overcome an energy barrier of $23.8 \mathrm{~kJ} \cdot \mathrm{mol}^{-1}$. 


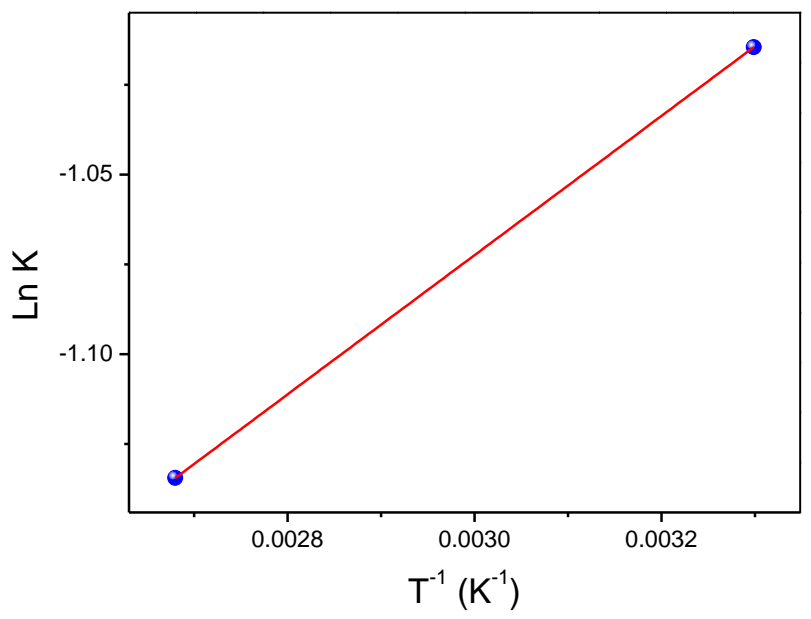

Figure 10. Variation of the pseudo-second order model constant with the absolute temperature for the adsorption process of $R B B$ dye in bacterial cellulose.

\subsection{Cytotoxicity assays in animal and myocrobia cells}

The residual water from the process with the best experimental condition was neutralized and only after that was the cytotoxicity assay performed against macrophage cells of the $\mathrm{J} 774$ strain (Figure 11A). The cells did not suffer significant cell death $(\mathrm{p}=0.0022)$. These values were confirmed due to the low nitric oxide production (Figure 11B). Yang et al. (2020) [74] removing methylene blue noted that the residual water was not cytotoxic against Chinese hamster ovary cells.
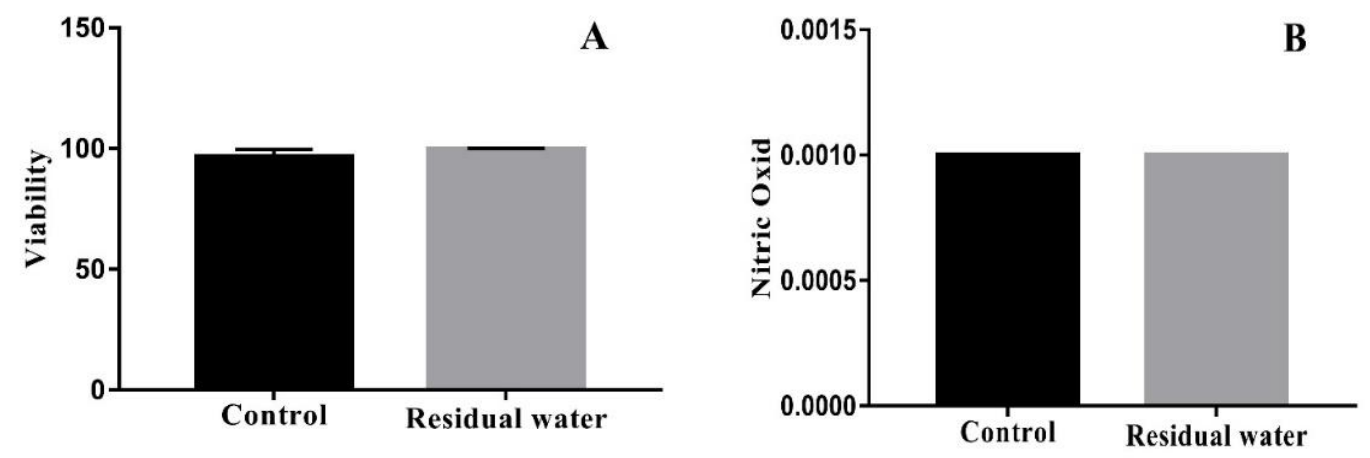

Figure 11. Cellular viability assessed by the MTT method in macrophages of the J774 strain treated with neutralized residual water $(A)$ and production of nitric oxide produced $(B)$. The horizontal bars represent the average of two experiments.

In addition to not being toxic to animal cells, it also did not cause death to the bacterial cells of this study Pseudomonas aeruginosa, Escherichia coli, Enterococcus faecalis and Staphylococcus aureus (Figure 12). Therefore, this water can be reused and has no harmful effects. 

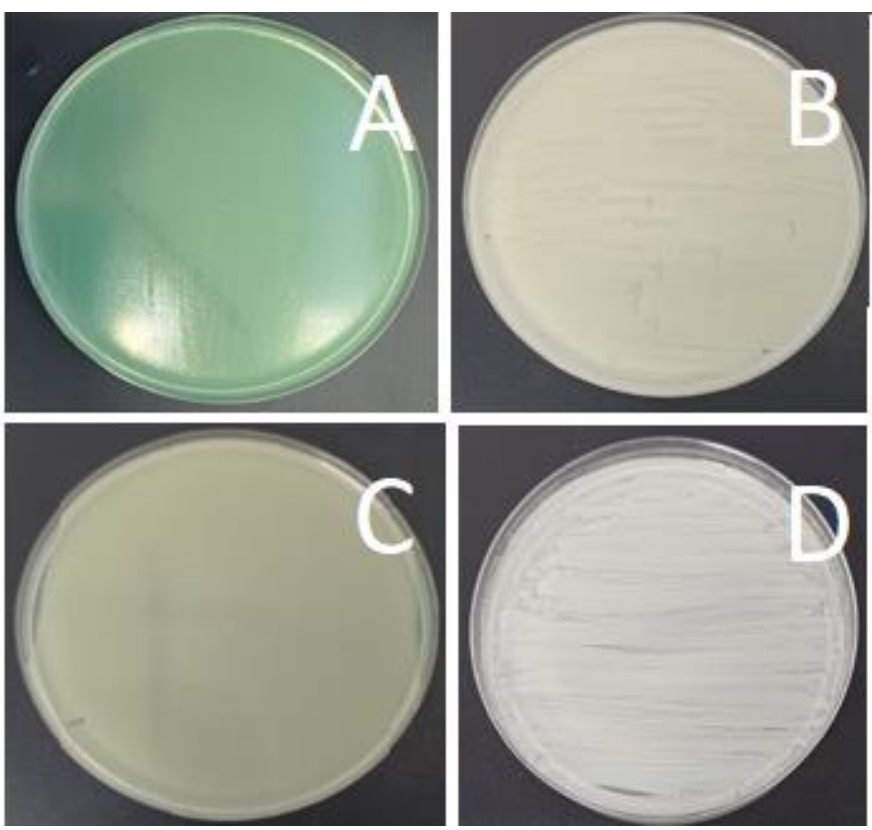

Figure 12. Growth of the microorganisms Pseudomonas aeruginosa (A), Escherichia coli (B), Enterococcus faecalis $(C)$ and Staphylococcus aureus $(D)$.

\section{CONCLUSION}

In this work, bacterial cellulose was used as an adsorbent for the removal of the Remazol Black $\mathrm{B}$ dye in aqueous solutions at different pHs. The results showed that at $\mathrm{pH} 3.5$ the best percentage of removal was $92 \%$ of the RBB dye. The kinetic study showed that the balance between the liquid and solid phases was reached in about 80 minutes and that the experimental data adjusted to the pseudo-second order model. The equilibrium tests showed that the experimental data fit the Langmuir model and that the increase in temperature causes a decrease in the adsorption capacity. The thermodynamic behavior of the adsorption was evaluated according to Gibbs' enthalpy, entropy and free energy. The value of Gibbs' free energy showed that the process is not favorable with increasing temperature. The negative enthalpy value confirms the exothermic nature of the adsorption process. And the negative entropy value suggests a reduction in the disorder of the adsorbate particles during the adsorption process. Thus, bacterial cellulose proved to be an economical and efficient alternative for the treatment of textile effluents containing the dye Remazol Black B.

\section{ACKNOWLEDGEMENTS}

This study was supported by Brazilian agencie Conselho Nacional de Desenvolvimento Científico e Tecnológico (CNPq)

\section{REFERENCES}

1. do Amaral MC, Zonatti WF, da Silva KL, Junior DK, Amato Neto J, Baruque-Ramos J. Industrial textile recycling and reuse in Brazil: Case study and considerations concerning the circular economy. Gest $\mathrm{e}$ Prod. 2018;25(3):431-43, doi: 10.1590/0104-530x3305

2. Mendes Júnior BDO, Junior M. Setor têxtil. Caderno Setorial ETENE. 2017;16:1-18.

3. Kant R. Textile dyeing industry an environmental hazard. Nat Sci. 2012;04(01):22-6, doi: 10.4236/ns.2012.41004

4. Gadekar MR, Ahammed MM. Use of water treatment residuals for colour removal from real textile dye wastewater. Appl Water Sci [Internet]. 2020;10(7):1-8, doi: 10.1007/s13201-020-01245-9 
5. Singh K, Arora S. Removal of synthetic textile dyes from wastewaters: A critical review on present treatment technologies. Crit Rev Environ Sci Technol. 2011;41(9):807-78, doi: $10.1080 / 10643380903218376$

6. Benkhaya S, M'Rabet S, El Harfi A. A review on classifications, recent synthesis and applications of textile dyes. Inorg Chem Commun. 2020;115:107891, doi: 10.1016/j.inoche.2020.107891

7. Lellis B, Fávaro-Polonio CZ, Pamphile JA, Polonio JC. Effects of textile dyes on health and the environment and bioremediation potential of living organisms. Biotechnol Res Innov. 2019;3(2):275-90, doi: 10.1016/j.biori.2019.09.001

8. Guaratini CCI, Zanoni MVB. Revisão: corantes têxteis. Quim Nova. 2000;23(1):71-8, doi: $10.1590 / \mathrm{S} 0100-40422000000100013$

9. Hynes NRJ, Kumar JS, Kamyab H, Sujana JAJ, Al-Khashman OA, Kuslu Y, et al. Modern enabling techniques and adsorbents based dye removal with sustainability concerns in textile industrial sector -A comprehensive review. J Clean Prod. 2020;272:122636, doi: 10.1016/j.jclepro.2020.122636

10. Donkadokula NY, Kola AK, Naz I, Saroj D. A review on advanced physico-chemical and biological textile dye wastewater treatment techniques. Rev Environ Sci Biotechnol. 2020;19(3):543-60, doi: $10.1007 / \mathrm{s} 11157-020-09543-\mathrm{z}$

11. Tara N, Siddiqui SI, Rathi G, Chaudhry SA, Inamuddin, Asiri AM. Nano-engineered adsorbent for the removal of dyes from water: A review. Curr Anal Chem. 2019;16(1):14-40, doi: $10.2174 / 1573411015666190117124344$

12. Al-Ghouti MA, Da'ana DA. Guidelines for the use and interpretation of adsorption isotherm models: A review. J Hazard Mater. 2020 Feb;393:122383, doi: 10.1016/j.jhazmat.2020.122383

13. Godage NH, Gionfriddo E. Use of natural sorbents as alternative and green extractive materials: A critical review. Anal Chim Acta. 2020;1125:187-200, doi: 10.1016/j.aca.2020.05.045

14. Andriani D, Apriyana AY, Karina M. The optimization of bacterial cellulose production and its applications: a review. Cellulose. 2020;27(12):6747-66, doi: 10.1007/s10570-020-03273-9

15. Wang J, Tavakoli J, Tang Y. Bacterial cellulose production, properties and applications with different culture methods - A review. Carbohydr Polym. 2019 Apr;219:63-76, doi: 10.1016/j.carbpol.2019.05.008

16. Hussain Z, Sajjad W, Khan T, Wahid F. Production of bacterial cellulose from industrial wastes: a review. Cellulose. 2019;26(5):2895-911, doi: 10.1007/s10570-019-02307-1

17. Hu Y, Liu F, Sun Y, Xu X, Chen X, Pan B, et al. Bacterial cellulose derived paper-like purifier with multifunctionality for water decontamination. Chem Eng J. 2019 Apr;371:730-7, doi: 10.1016/j.cej.2019.04.091

18. Chen X, Cui J, Xu X, Sun B, Zhang L, Dong W, et al. Bacterial cellulose/attapulgite magnetic composites as an efficient adsorbent for heavy metal ions and dye treatment. Carbohydr Polym. 2020;229:115512, doi: $10.1016 /$ j.carbpol.2019.115512

19. Ali A, Mohammad EY, Abosaeed R, Ramin K, Abbas R. Biosorption thermodynamic and kinetic of direct dye from aqueous solutions on bacterial cellulose. African J Microbiol Res. 2012;6(6):1270-8, doi: 10.5897/ AJMR11.1506

20. Khamkeaw A, Jongsomjit B, Robison J, Phisalaphong M. Activated carbon from bacterial cellulose as an effective adsorbent for removing dye from aqueous solution. Sep Sci Technol. 2019;54(14):2180-93, doi: $10.1080 / 01496395.2018 .1541906$

21. Huang X, Li B, Wang S, Yue X, Zhengguo Y, Deng X, et al. Facile in-situ synthesis of PEI-Pt modified bacterial cellulose bio-adsorbent and its distinctly selective adsorption of anionic dyes. Colloids Surfaces A Physicochem Eng Asp. 2020;586:124163, doi: 10.1016/j.colsurfa.2019.124163

22. Coimbra CGO. Produção de celulose bacteriana por Gluconacetobacter xylinus e elaboração de filmes comestíveis (tese). Recife (PE): Universidade Federal de Pernambuco; 2016.

23. Silva FC, da Silva MMF, Lima LCB, Osajima JA, da Silva Filho EC. Modifying cellulose with metaphosphoric acid and its efficiency in removing brilliant green dye. Int $\mathrm{J}$ Biol Macromol. 2018;114:470-8, doi: 10.1016/j.ijbiomac.2018.03.089

24. Hassan A, Sorour NM, El-Baz A, Shetaia Y. Simple synthesis of bacterial cellulose/magnetite nanoparticles composite for the removal of antimony from aqueous solution. Int J Environ Sci Technol. 2019;16(3):1433-48, doi: 10.1007/s13762-018-1737-4

25. Cruz IJ, Marques LM, de Souza KC, de Lima VF, Marques OM, do Nascimento Junior AJ. Remoção do corante remazol black b pelo uso da biomassa mista de Aspergillus niger e capim elefante (Pennisetum purpureum schum). Engevista. 2016;18(2):265, doi: 10.22409/engevista.v18i2.727

26. Nascimento ACC, Cruz Filho IJ, Lima VF, do Nascimento Junior AJ, Marques OM, Gondim MVS. Biosorption of the dye indigo carmine by Pennisetum purpureum Schumach. 1827. (Poales: Poaceae) (Elephant grass). J Environ Anal Prog. 2017 Jul;02(01):44-9, doi: 10.24221/jeap.2.1.2017.1033.44-49 
27. Hasanzadeh M, Simchi A, Far HS. Kinetics and adsorptive study of organic dye removal using waterstable nanoscale metal organic frameworks. Mater Chem Phys. 2019;233:267-75, doi: 10.1016/j.matchemphys.2019.05.050

28. Alexandre JIDS, Santos Neto SMD, Coutinho AP, Melo TDATD, Gonçalves EAP, Gondim MVS, Oliveira ALD. Sorption of the Direct Black 22 dye in alluvial soil. Rev Ambient Água. 2020;15(4):e2483, doi: 10.4136/ambi-agua.2483

29. Alves ATA, Silva LTMDS, Alcântara LRPD, Barros VHDO, Santos Neto SMD, Lima VFD, Antonino ACD. Sorption of Remazol Black B dye in alluvial soils of the Capibaribe River Basin. Rev Ambient Água. 2020;15(2):e2491, doi: 10.4136/ambi-água.2491

30. Won SW, Kim HJ, Choi SH, Chung BW, Kim KJ, Yun YS. Performance, kinetics and equilibrium in biosorption of anionic dye Reactive Black 5 by the waste biomass of Corynebacterium glutamicum as a low-cost biosorbent. Chem Eng J. 2006;121(1):37-43, doi: 10.1016/j.cej.2006.04.005

31. Dotto GL, Vieira MLG, Gonçalves JO, Pinto LAA. Remoção dos corantes azul brilhante, amarelo crepúsculo e amarelo tartrazina de soluções aquosas utilizando carvão ativado, terra ativada, terra diatomácea, quitina e quitosana: estudos de equilíbrio e termodinâmica. Quim Nova. 2011;34(7):1193-9, doi: 10.1590/S0100-40422011000700017.

32. El Maguana Y, Elhadiri N, Benchanaa M, Chikri R. Adsorption thermodynamic and kinetic studies of methyl orange onto sugar scum powder as a low-cost inorganic adsorbent. J Chem. 2020;2020:9165874, doi: $10.1155 / 2020 / 9165874$

33. Souza NHC, Ferrari RAM, Silva DFT, Nunes FD, Bussadori SK, Fernandes KPS. Effect of low-level laser therapy on the modulation of the mitochondrial activity of macrophages. Brazilian J Phys Ther. 2014;18(4):308-14, doi: 10.1590/bjpt-rbf.2014.0046

34. Ding J, Zhang J, Li J, Li D, Xiao C, Xiao H, et al. Electrospun polymer biomaterials. Prog Polym Sci. 2019;90:1-34, doi : 10.1016/j.progpolymsci.2019.01.002

35. Mikkelsen D, Flanagan BM, Dykes GA, Gidley MJ. Influence of different carbon sources on bacterial cellulose production by Gluconacetobacter xylinus strain ATCC 53524. J Appl Microbiol. 2009;107(2):576-83, doi: 10.1111 / j.1365-2672.2009.04226

36. Lopes TD, Riegel-Vidotti IC, Grein A, Tischer CA, Faria-Tischer PCS. Bacterial cellulose and hyaluronic acid hybrid membranes: Production and characterization. Int J Biol Macromol. 2014;67:401-8, doi: 10.1016/j.ijbiomac.2014.03.047

37. Salari M, Sowti Khiabani M, Rezaei Mokarram R, Ghanbarzadeh B, Samadi Kafil H. Preparation and characterization of cellulose nanocrystals from bacterial cellulose produced in sugar beet molasses and cheese whey media. Int J Biol Macromol. 2019;122:280-8, doi: 10.1016/j.jbiomac.2018.10.136

38. Gayathri G, Srinikethan G. Bacterial Cellulose production by K. saccharivorans BC1 strain using crude distillery effluent as cheap and cost effective nutrient medium. Int J Biol Macromol. 2019;138:950-7, doi: 10.1016/j.ijbiomac.2019.07.159

39. Cheng R, Kang M, Zhuang S, Shi L, Zheng X, Wang J. Adsorption of Sr(II) from water by mercerized bacterial cellulose membrane modified with EDTA. J Hazard Mater. 2019;364:645-53, doi: 10.1016/j.jhazmat.2018.10.083

40. Zhuang S, Wang J. Removal of U(VI) from aqueous solution using phosphate functionalized bacterial cellulose as efficient adsorbent. Radiochim Acta. 2019;107(6):459-67, doi: 10.1515/ract-2018-3077

41. Bagewadi ZK, Bhavikatti JS, Muddapur UM, Yaraguppi DA, Mulla SI. Statistical optimization and characterization of bacterial cellulose produced by isolated thermophilic Bacillus licheniformis strain ZBT2. Carbohydr Res. 2020;491:107979, doi: 10.1016/j.carres.2020.107979

42. Chawla PR, Bajaj IB, Survase SA, Singhal RS. Microbial cellulose: Fermentative production and applications. Food Technol Biotechnol. 2009;47(2):107-24.

43. Donini IA, de Salvi DT, Fukumoto FK, Lustri WR, Barud HS, Marchetto R, Ribeiro SJ. Biossíntese e recentes avanços na produção de celulose bacteriana. Eclética Química. 2010;35(4):165-178, doi: 10.1590/S0100-46702010000400021

44. Kiziltas EE, Kiziltas A, Blumentritt M, Gardner DJ. Biosynthesis of bacterial cellulose in the presence of different nanoparticles to create novel hybrid materials. Carbohydr Polym. 2015;129:148-55, doi: 10.1016/j.carbpol.2015.04.039

45. Vasconcelos NF, Feitosa JPA, da Gama FMP, Morais JPS, Andrade FK, de Souza Filho MSM, et al. Bacterial cellulose nanocrystals produced under different hydrolysis conditions: Properties and morphological features. Carbohydr Polym. 2017;155:425-31, doi: 10.1016/j.carbpol.2016.08.090

46. Sousa RB, Dametto AC, Sábio RM, de Carvalho RA, Vieira EG, Oliveira AFA, et al. Cerium-doped calcium phosphates precipitated on bacterial cellulose platform by mineralization. Ceram Int. 2020;46(17):26985-90, doi: 10.1016/j.ceramint.2020.07.175

47. Elizalde-González MP, Geyer W, Guevara-Villa MRG, Mattusch J, Peláez-Cid AA, Wennrich R. Characterization of an adsorbent prepared from maize waste and adsorption of three classes of textile 
dyes. Colloids Surfaces A Physicochem Eng Asp. 2006;278(1-3):89-97, doi: 10.1016/j.colsurfa.2005.11.097

48. Cruz Filho IJD, Ferreira HKL, Silva SKGD, Machado SEF, Zaidan LEMC, Lima VFD, Nascimento Junior AJD. Otimização do processo de remoção do corante preto de remazol B por uso de biomassa mista de Aspergillus niger van Tieghem, 1867 (Ascomycota: Trichocomaceae) e Pennisetum purpureum Schumach., 1827 (Poales: Poaceae). Revista Brasileira de Gestao Ambiental e Sustentabilidade. 2016;3(6):375-384, doi: 10.21438/rbgas.030611

49. Jawad AH, Razuan R, Appaturi JN, Wilson LD. Adsorption and mechanism study for methylene blue dye removal with carbonized watermelon (Citrullus lanatus)rind prepared via one-step liquid phase $\mathrm{H} 2$ SO 4 activation. Surfaces and Interfaces. 2019;16:76-84, doi: 10.1016/j.surfin.2019.04.012

50. Tanhaei B, Ayati A, Sillanpää M. Magnetic xanthate modified chitosan as an emerging adsorbent for cationic azo dyes removal: Kinetic, thermodynamic and isothermal studies. Int $\mathrm{J}$ Biol Macromol. 2019;121:1126-34, doi: 10.1016/j.ijbiomac.2018.10.137

51. Değermenci GD, Değermenci N, Ayvaoğlu V, Durmaz E, Çakır D, Akan E. Adsorption of reactive dyes on lignocellulosic waste; characterization, equilibrium, kinetic and thermodynamic studies. J Clean Prod. 2019;225:1220-9, doi: 10.1016/j.jclepro.2019.03.260

52. Naushad M, Alqadami AA, AlOthman ZA, Alsohaimi IH, Algamdi MS, Aldawsari AM. Adsorption kinetics, isotherm and reusability studies for the removal of cationic dye from aqueous medium using arginine modified activated carbon. J Mol Liq. 2019;293:111442, doi: 10.1016/j.molliq.2019.111442

53. Parshi N, Pan D, Dhavle V, Jana B, Maity S, Ganguly J. Fabrication of lightweight and reusable salicylaldehyde functionalized chitosan as adsorbent for dye removal and its mechanism. Int $\mathbf{J}$ Biol Macromol. 2019;141:626-35, doi: 10.1016/j.ijbiomac.2019.09.025

54. Ziapour AR, Sefidrooh M, Moadeli MR. Adsorption of Remazol black B dye from aqueous solution using bagasse. Prog Color Color Coatings. 2016;9(2):99-108, doi: 10.30509 / PCCC.2016.75881

55. Madan S, Shaw R, Tiwari S, Tiwari SK. Adsorption dynamics of Congo red dye removal using ZnO functionalized high silica zeolitic particles. Appl Surf Sci. 2019;487:907-17, doi: 10.1016/j.apsusc.2019.04.273

56. Vergis BR, Kottam N, Hari Krishna R, Nagabhushana BM. Removal of Evans Blue dye from aqueous solution using magnetic spinel $\mathrm{ZnFe} 2 \mathrm{O} 4$ nanomaterial: Adsorption isotherms and kinetics. NanoStructures and Nano-Objects. 2019;18:100290, doi: 10.1016/j.nanoso.2019.100290

57. Jawad AH, Abdulhameed AS. Mesoporous Iraqi red kaolin clay as an efficient adsorbent for methylene blue dye: Adsorption kinetic, isotherm and mechanism study. Surfaces and Interfaces. 2020;18:100422, doi: 10.1016/j.surfin.2019.100422

58. Demirbas A. Heavy metal adsorption onto agro-based waste materials: A review. J Hazard Mater. 2008;157(2-3):220-9, doi: 10.1016/j.jhazmat.2008.01.024

59. Khattri SD, Singh MK. Colour removal from synthetic dye wastewater using a bioadsorbent. Water Air Soil Pollut. 2000;120(3-4):283-94, doi: 10.1023/A:1005207803041

60. Aksu Z, Tezer S. Biosorption of reactive dyes on the green alga Chlorella vulgaris. Process Biochem. 2005;40(3-4):1347-61, doi: 10.1016/j.procbio.2004.06.007

61. Al-Ghouti M, Khraisheh MAM, Ahmad MNM, Allen S. Thermodynamic behaviour and the effect of temperature on the removal of dyes from aqueous solution using modified diatomite: A kinetic study. $\mathbf{J}$ Colloid Interface Sci. 2005;287(1):6-13, doi: 10.1016/j.jcis.2005.02.002

62. Srinivasan A, Viraraghavan T. Decolorization of dye wastewaters by biosorbents: A review. J Environ Manage. 2010;91(10):1915-29, doi: 10.1016/j.jenvman.2010.05.003

63. El-Zawahry MM, Abdelghaffar F, Abdelghaffar RA, Hassabo AG. Equilibrium and kinetic models on the adsorption of Reactive Black 5 from aqueous solution using Eichhornia crassipes/chitosan composite. Carbohydr Polym. 2016;136:507-15, doi: 10.1016/j.carbpol.2015.09.071

64. Felista MM, Wanyonyi WC, Ongera G. Adsorption of anionic dye (Reactive black 5) using macadamia seed Husks: Kinetics and equilibrium studies. Sci African. 2020;7:e00283, doi: 10.1016/j.sciaf.2020.e00283

65. Xiao H, Peng H, Deng S, Yang X, Zhang Y, Li Y. Preparation of activated carbon from edible fungi residue by microwave assisted $\mathrm{K} 2 \mathrm{CO} 3$ activation-Application in reactive black 5 adsorption from aqueous solution. Bioresour Technol. 2012;111:127-33, doi: 10.1016/j.biortech.2012.02.054

66. Furlan FR, Silva LGDM, Morgado AF, Souza AAU. Removal of reactive dyes from aqueous solutions using combined coagulation/flocculation and adsorption on activated carbon. Resour Conserv Recycl. 2010;54(5):283-90, doi: 10.1016/j.resconrec.2009.09.001

67. Annadurai G. Adsorption of basic dye on strongly chelating polymer: Batch kinetics studies. Iran Polym J (English). 2002 Jul-Aug;11(4):237-44. 
68. Kim MH, Hwang CH, Kang S Bin, Kim S, Park SW, Yun YS, et al. Removal of hydrolyzed Reactive Black 5 from aqueous solution using a polyethylenimine-polyvinyl chloride composite fiber. Chem Eng J. 2015;280:18-25, doi: 10.1016/j.cej.2015.05.069

69. Al-Degs Y, Khraisheh MAM, Allen SJ, Ahmad MN. Effect of carbon surface chemistry on the removal of reactive dyes from textile effluent. Acta Physiol Scand. 2000;34(2):927-35, doi: 10.1016/S00431354(99)00200-6

70. Sharma P, Saikia BK, Das MR. Removal of methyl green dye molecule from aqueous system using reduced graphene oxide as an efficient adsorbent: Kinetics, isotherm and thermodynamic parameters. Colloids Surfaces A Physicochem Eng Asp. 2014;457(1):125-33, doi: 10.1016/j.colsurfa.2014.05.054

71. Liu Y, Liu YJ. Biosorption isotherms, kinetics and thermodynamics. Sep Purif Technol. 2008;61(3):22942, doi: 10.1016/j.seppur.2007.10.002

72. Chinoune K, Bentaleb K, Bouberka Z, Nadim A, Maschke U. Adsorption of reactive dyes from aqueous solution by dirty bentonite. Appl Clay Sci. 2016;123:64-75, doi: 10.1016/j.clay.2016.01.006

73. Deng L, Su Y, Su H, Wang X, Zhu X. Sorption and desorption of lead (II) from wastewater by green algae Cladophora fascicularis. J Hazard Mater. 2007;143(1-2):220-5, doi: 10.1016/j.jhazmat.2006.09.009

74. Yang HC, Chao MW, Chou CJ, Wang KH, Hu C. Mushroom waste-derived g-C3N4 for methyl blue adsorption and cytotoxic test for Chinese hamster ovary cells. Matchemphys. 2020;244:122715, doi: 10.1016/j.matchemphys.2020.122715 